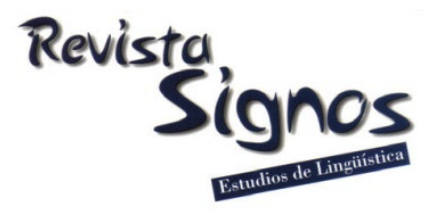

\title{
Grammar features and discourse style in digital genres: The case of science-focused crowdfunding projects
}

\author{
Rasgos gramaticales y estilo discursivo en géneros digitales: El \\ caso de los proyectos de micromecenazgo
}

\author{
Carmen Pérez-Llantada \\ UNIVERSIDAD DE ZARAGOZA \\ ESPAÑA \\ llantada@unizar.es
}

Recibido: 04-IV-2019 / Aceptado: 04-V-2020

DOI: $10.4067 /$ S0718-09342021000100073

\begin{abstract}
As advances in digital media render new forms of knowledge dissemination, new genres in the Internet are attracting increasing scholarly attention. Yet, although these genres have been investigated extensively from the perspectives of rhetoric and discourse, research on their linguistic features is limited. To fill this gap, this study analyses grammar features and their functional associations in a corpus of crowdfunding project proposals. The study shows that these proposals are characterised by a structurally elaborate (not compressed) discourse style, with a high presence of both complex noun phrases containing post-modification and/or (finite and non-finite) clauses and verb phrases controlling subordinate clauses that make meanings very explicit. Salient among the findings is the hybrid discourse style of these proposals. Their style shows linguistic features associated with formal academic prose (complex noun phrases, phrases with embedded relative clauses with que, non-finite infinitive and participle clauses, and prepositional phrases as nominal post-modifiers) as well as features that are especially common in conversation (verb phrases encapsulating first person pronouns, and verb phrases with epistemic/deontic modals and non-face threatening expressions of modality). It is concluded that the hybridisation of this genre, as reflected in the use of linguistic features, is functionally motivated by the various communicative purposes of the genre-to inform about science, educate in science and create a persuasive appeal to prompt donation.
\end{abstract}

Key Words: Genre analysis, structural elaboration, densification, colloquial features, interdiscursivity. 


\section{Resumen}

A medida que las tecnologías contribuyen al surgimiento de géneros en entornos digitales, estos géneros van acaparando un creciente interés en el ámbito investigador. No obstante, si bien estos géneros se han analizado principalmente desde las perspectivas de la retórica y del análisis del discurso, son escasos los estudios centrados en rasgos lingüísticos. El objetivo de este estudio es identificar los rasgos lingüísticos (gramaticales) y el estilo discursivo que caracterizan un género digital emergente, el de los proyectos de ciencia orientados al micromecenazgo en España. Los resultados indican que estos textos se caracterizan por un discurso estructuralmente elaborado, con un uso muy frecuente de sintagmas nominales complejos (con post-modificación y estructuras de subordinación), así como de sintagmas verbales de los que dependen oraciones subordinadas que hacen que el contenido semántico que se comunica sea muy explícito. Un hallazgo importante es que el género se caracteriza por un estilo discursivo híbrido, en tanto que combina elementos gramaticales asociados a la escritura académica formal (nombres, oraciones relativas con 'que', oraciones regidas por infinitivos y participios, y sintagmas preposicionales que actúan como postmodificadores en sintagmas nominales) y al registro conversacional (verbos, pronombres de primera persona, modales epistémicos y deónticos y expresiones de atenuación). Se concluye que este estilo discursivo híbrido responde a múltiples propósitos comunicativos del género-informar sobre ciencia, educar en ciencia e instar al micromecenazgo.

Palabras Clave: Análisis de género, estructuras elaboradas, densificación, rasgos coloquiales, interdiscursividad.

\section{INTRODUCTION}

Profiting from Web 2.0 technologies, public communication of science is gaining momentum. Web-mediated genres have emerged that respond to new social exigences such as the need to disseminate scientific knowledge beyond expert audiences and support and enhance 'scientific culture' or 'scientific literacy', namely, the broad publics' understanding of science (Herring, 2013; Giltrow \& Stein, 2006; Giltrow, 2017; Kelly \& Miller, 2016; Miller \& Kelly, 2017). One key issue that the scholarly literature underlines regarding these emerging genres and new forms of digital communication is that the form and substance of the genres is shaped and constrained by the fact that they target audiences with different backgrounds, interests and expectations (Burns, O'Connor \& Stocklmayer, 2003; Hyland, 2010, 2018; Caliendo, 2012; Gotti, 2014; Scotto di Carlo, 2014; Engberg \& Maier, 2015; Motta Roth \& Scotti Scherer, 2016; Luzón, 2017). Burns et al. (2003: 3) define 'diversified audiences' as those encompassing people who can be either "reasonably well-informed about science and scientific activities" or "interested in but not necessarily well-informed about science", or scientists in other fields, or "decision makers" (e.g. in government, industry and scientific institutions), or even science practitioners "directly involved in some aspect of the practice of science". Bearing in mind the issue of audience diversification, it seems evident that digital genres pose challenges to scientists, who now need to engage in "appropriate skills, media, activities, and dialogue" to produce 
diverse responses to science, "awareness, enjoyment, interest, opinion-forming, and understanding" (Burns et al., 2003: 187). A succinct review of rhetorical, discourse and linguistic approaches to genre uptake in media environments is provided below.

\section{Theoretical framework}

\subsection{Digital genres for science dissemination}

Web 2.0 has become an increasingly popular form of communicating scientific advances to lay audiences (Herring, 2013; Gross \& Buehl, 2016; Kelly \& Miller, 2016; Miller \& Kelly, 2017) and has turned science communication into a complex rhetorical exercise. It involves the construction of texts that need to communicate expert knowledge effectively to audiences with different knowledge backgrounds, different levels of awareness of scientific outreach, and level of understanding of scientific contents in such a way that these audiences are able to interpret and form a personal opinion about the science that is communicated. This can be seen in genres such as science blogs, research group websites, TED talks, microblogging (Twitter), and science popularisation genres such as didactic reportages, infomercials and news in online journals (Caliendo, 2012; Motta Roth \& Scotti Scherer, 2016; Mehlenbacher, 2017; Miller \& Kelly, 2017). To date, genre uptake has been mostly investigated from the perspectives of rhetoric and discourse. Giltrow (2017) and Herring (2013) explain that emerging digital genres are not new, but rather generic hybrids that draw on the form and substance of existing genres and enhance them using the affordances of Web 2.0. Discourse studies on genre, register and style draw on the conceptualisation of 'discourse style' to describe language variation in written and spoken texts (Parodi, 2015; Biber \& Gray, 2016; Biber \& Conrad, 2019). These studies have specifically looked into the extent to which linguistic features in web-mediated communication are similar to the linguistic features that are very common in spoken and written registers. As an example, the discourse style of genres such as personal homepages, research group blogs, science blogs and microblogging has been characterised as exhibiting colloquial features associated with conversation (Barbieri, 2018; Hyland, 2010, 2018; Luzón, 2017), which recalls Biber and Gray's (2016) claim that there is an increasing 'colloquialisation' of written texts in digital media. Research also contends that the functional goals associated with the linguistic features of these texts are to construct a credible online identity, assert the researchers' professionalism and create proximity with readers. Studies on spoken genres such as TED Talks also report the use of conversational features such as deictics, person pronouns (I/you) and inclusive we-pronouns to communicate expert knowledge while conveying "a certain degree of informality and colloquialism" (Caliendo, 2012: 101). It is also argued that TED Talk presenters use stance markers to express judgments and position themselves subjectively (Scotto di Carlo, 2014). 
The need to recontextualise expert knowledge, a process referred to as 'genre transmediality' or 'transmedial gradation' (Engberg \& Maier, 2015) has also raised the issue of hybridisation in genres that reach diversified audiences. One clear example of processes of transmedial gradation can be found in science popularisation genres. These draw on strategies such as reformulation and rephrasing of expert knowledge for both "argumentative and promotional purposes" (Gotti, 2014: 15). Motta Roth and Scotti Scherer (2016) examine 'interdiscursivity' in science popularisation genres and contend that these genres borrow features of scientific discourse, journalistic discourse and pedagogical discourse to inform about scientific contents, 'sell' the value of their scientific work and teach science to a general public. Digital projects in crowdfunding websites (e.g. Kickstarter, Experiment.com, Crowd.science, Rockethub and GoFundMe) also instantiate what Herring (2013) defines as generic hybrids. They borrow features of an existing genre, the research project proposal, and deploy the multimodal resources of Web 2.0 to enhance the form and substance of its generic antecedent. Mehlenbacher (2017: 133) explains that 'Kickstarter' proposals adopt the rhetorical moves and steps of research project proposal ("establishing an exigence establishing a response - occupying the response - stating achievements - claiming benefits - outlining means - claiming competence - claiming importance - summary") and use multimodal elements (photographs) to build more convincing arguments and appeal to emotions. Paulus and Roberts (2018: 65) likewise describe online medical campaigns in GoFundMe as "more vocal, photogenic, or emotionally appealing" in the very formulation of requests for funding so as to construct a strong identity of the individual in need of assistance and financial help. It is through the combination of verbal and visual elements that the narrative becomes more credible and the "real-life superhero" worthy of receiving donation (Paulus \& Roberts, 2018: 70).

Yet, while the above-mentioned studies have considerably broadened our understanding of the rhetoric and the communicative purposes of emerging digital genres, enquiry into linguistic features is limited to date. Using a lexical-bundle approach to analyse American blogs, Barbieri (2018) explicitly notes that there are few comprehensive studies that investigate whether digital genres can be characterised by lexicogrammar that is highly frequent in conversation (e.g. first person pronouns conveying stance and verb-phrase structures) and/or lexicogrammar associated with informational written registers (e.g. bundles performing referential functions in discourse). Parodi (2015, see also 2010) stresses the value of investigating "the linguistic cartography of a specific genre" to understand the functionality of linguistic features that make one genre recognizable from others. Of particular interest for the present study is Parodi's (2015: 476) claim that the 'discourse organisation mode' narrative, descriptive, argumentative - is operationalised through grammatical features such as personal pronouns, periphrastic forms of future tense, among others, that reflect different degrees of complexity and informational density across written texts. 
Linguistic approaches for register and genre identification in social network and media communication provide further evidence of language variation and, in particular, colloquialisation in web-mediated written texts. In their analysis of Spanish in Facebook, Tuenti and Twitter, Mancera and Pano (2013) identify the presence of conversational features (deixis, colloquial syntactic structures and intensifiers) that allow writers to position themselves towards propositional content and, at the same time, to create proximity with their readers. Moya and Carrió-Pastor (2018a, 2018b) also report the use of colloquial/conversational features such as intensifiers and mitigation resources in online comments in Spanish and Chilean digital newspapers for similar rhetorical intentions. In describing the interface of grammar, discourse and pragmatics, Mancera (2018) likewise stresses the role of linguistic features by noting that the function of mitigation resources in Spanish online reviews is to convey different degrees of assertiveness.

\subsection{Aim of the study}

In their article "Challenging stereotypes about academic writing: Complexity, elaboration, explicitness", Biber and Gray (2010: 2) contest the stereotypical view of academic writing in English as "grammatically complex, with elaborated structures, and with meaning relations expressed explicitly". They propose the view of formal academic English writing as structurally compressed, with a recurring use of phrasal (non-clausal) modifiers embedded in noun phrases. These linguistic features make the expression of contents concise and meanings less explicit and informationally dense (Biber, Johansson, Leech, Conrad \& Finegan, 1999). Leech, Hundt, Mair and Smith (2009: 245) also refer to densification as a defining characteristic of registers that oppose colloquialisation (i.e. registers that exhibit spoken grammar features). Biber and Gray (2016: 326) point out that greater reliance on phrasal rather than clausal patterns/structures (characteristic of formal academic writing in English) accounts in effect for "informational purposes/goals".

Spanish has been defined as "a major international language with a long social history of literacy, and it is a Romance language, with interesting linguistic similarities to, and differences from, English" (Biber, Davies, Jones \& Tracy-Ventura, 2008: 1). Drawing on previous linguistic descriptions of English and Spanish spoken and written texts (Biber et al., 1999; Parodi, 2010, 2015), and on the broad framework of genres in the Internet (Herring, 2013; Kelly \& Miller, 2016; Miller \& Kelly, 2017), this study sought to identify the linguistic features characterising crowdfunding projects. The broad research questions that guided the investigation were the following:

RQ1: What grammatical features characterise the genre of crowdfunding project proposals and what are the functions of these features in communicating meaning?

RQ2: What is the discourse style of crowdfunding projects in terms of grammatical complexity, elaboration and degree of explicitness of meanings? 
RQ3: What situational and genre constraints account for the communicative functionality of the grammar of these projects?

The study sought to be exploratory and preparatory of in-depth linguistic and multimodal analysis of this genre in Spanish and English in future research.

\section{Methods}

\subsection{Corpus description}

For the present study a small-scale corpus of proposals for crowdfunding biomedical research $(n=10)$ was retrieved from Precipita ${ }^{1}$, the Spanish Foundation for Science and Technology (FECYT)'s platform for crowdfunding Spanish science under the motto "Activating collective science". Both the main online texts of the proposals (totalling 8,247 words) and their corresponding hyperlinked expanded texts, that were downloadable in pdf form by clicking on a 'More information about the project' button (16,026 words), were analysed. Wordsmith Tools v.5 was used to retrieve the overall corpus statistics and compute tokens (running words in text), types (the number of distinct words in each subset of texts) and type/token ratios (TTR) (Table $1)$.

Table 1. Overall corpus statistics data.

\begin{tabular}{|l|c|c|c|c|c|c|}
\hline \multicolumn{1}{|c|}{ Text file } & Tokens & Types & Type/token ratio & Sentences & Mean (in words) & Std. dev. \\
\hline 1_main text & 976 & 402 & 41,875 & 35 & 27,428574 & 11,515427 \\
\hline 1_expanded text & 1810 & 640 & 35,894558 & 77 & 23,168833 & 12,922239 \\
\hline 2_main text & 777 & 315 & 40,909092 & 27 & 28,51852 & 15,55232 \\
\hline 2_expanded text & 765 & 312 & 41,434261 & 31 & 24,290325 & 14,713244 \\
\hline 3_main text & 576 & 273 & 48,576511 & 21 & 26,761904 & 22,288797 \\
\hline 3_expanded text & 2122 & 699 & 34,332024 & 75 & 27,146669 & 19,234465 \\
\hline 4_main text & 1253 & 488 & 39,418415 & 57 & 21,719303 & 15,082811 \\
\hline 4_expanded text & 1805 & 656 & 36,525612 & 76 & 23,631578 & 16,043976 \\
\hline 5_main text & 776 & 295 & 38,411457 & 36 & 21,333332 & 11,88276 \\
\hline 5_expanded text & 1035 & 431 & 42,842941 & 48 & 20,958332 & 11,601464 \\
\hline 6_main text & 500 & 267 & 54,378819 & 21 & 23,380953 & 13,832846 \\
\hline 6_expanded text & 637 & 319 & 51,121796 & 30 & 20,799999 & 13,988666 \\
\hline 7_main text & 896 & 336 & 38,356163 & 33 & 26,545456 & 14,426735 \\
\hline 7_expanded text & 2848 & 732 & 26,416456 & 104 & 26,64423 & 17,078869 \\
\hline 8_main text & 886 & 360 & 41,18993 & 28 & 31,214287 & 18,113544 \\
\hline 8_expanded text & 1972 & 717 & 36,93972 & 71 & 27,338026 & 17,81568 \\
\hline 9_main text & 1002 & 423 & 42,512562 & 37 & 26,89189 & 16,518984 \\
\hline 9_expanded text & 2107 & 645 & 30,950096 & 71 & 29,352112 & 16,127258 \\
\hline 10_main text & 605 & 288 & 48,241207 & 22 & 27,136366 & 20,741713 \\
\hline 10_expanded text & 925 & 380 & 42,316257 & 37 & 24,297297 & 15,638032 \\
\hline
\end{tabular}

\subsection{Study design}

The design of the study was motivated by Biber, Davies, Jones and Tracy-Ventura (2008: 3) claim that the "cross-linguistic and cross-cultural perspective" enables us to 
establish "points of similarity to and differences" between English and Spanish. Because the present study sought to be a starting point for future comparative linguistic descriptions of English and Spanish in digital scientific genres, Biber et al.'s (1999) taxonomy of phrase types - noun phrases, prepositional phrases, adjective phrases, adverb phrases and verb phrases- was adopted to develop a corpus-driven taxonomy of phrase types in Spanish that could be comparable with that of English. To identify the different phrase types and how they add meaning at the sentence level in the genre analysed, that of crowdfunding proposals, codes were created deductively (i.e. free codes). The initial hand coding drew on corpus-driven procedures and was based on 5 free codes (each of them representing a phrase type) and 13 free sub-codes for the identification of sub-categories within each phrase type (Table 2). Top level phrases are marked in [].

Table 2. Taxonomy of phrase types.

\begin{tabular}{|c|c|c|}
\hline codes & sub-codes & examples \\
\hline \multirow[t]{4}{*}{$\begin{array}{l}\text { Noun- } \\
\text { Phrase }\end{array}$} & Simple NP & $\begin{array}{l}{[\text { El tratamiento] }]^{\mathrm{NP}} \text { depende del ...; ... pueden sufrir [una }} \\
\text { neuropatía] }\end{array}$ \\
\hline & $\begin{array}{l}\text { NP with pre/post- } \\
\text { modification }\end{array}$ & $\begin{array}{l}{[\text { La leucemia aguda linfoblástica }]^{\mathrm{NP}} \ldots ; \text { [el uso de distintos }} \\
\text { métodos diagnósticos] }]^{\mathrm{NP}}\end{array}$ \\
\hline & $\begin{array}{l}\text { NP with embedded } \\
\text { clause(s) }\end{array}$ & [tests que sean más sensibles y específicos] $]^{N P}$ \\
\hline & $\begin{array}{l}\text { NPs with pre/post- } \\
\text { modification and } \\
\text { embedded clause(s) }\end{array}$ & $\begin{array}{l}\text { la superioridad de la colonoscopia para detectar este tipo de } \\
\text { lesión] }{ }^{N P} \text {; [una de las causas principales que contribuyen a la } \\
\text { alta mortalidad] }\end{array}$ \\
\hline \multirow{5}{*}{$\begin{array}{l}\text { Prep- } \\
\text { Phrase }\end{array}$} & Simple PrepP & [Tras la recaída] PrepP; [en el seguimiento] $]^{\text {PrepP }}$ \\
\hline & $\begin{array}{l}\text { PrepP with pre/post- } \\
\text { modification }\end{array}$ & {$[$ los efectos de los inhibidores de EGFR in vivo] PrepP } \\
\hline & \multirow{2}{*}{$\begin{array}{l}\text { PrepP with embedded } \\
\text { clause(s) }\end{array}$} & [entre los individuos que recibieron exámenes anuales] ${ }^{\text {PrepP }}$ \\
\hline & & [en los efectos antitumorales que hemos observado] ${ }^{\text {PrepP; }}$ \\
\hline & $\begin{array}{l}\text { PrepP with pre/post- } \\
\text { modification and } \\
\text { embedded clause(s) }\end{array}$ & $\begin{array}{l}\text { [con células con una capacidad terapéutica que actualmente } \\
\text { comienza en ... }]^{\text {Prepp}} \text {; [en el despliegue de técnicas para evaluar } \\
\text { la respuesta de .... }]^{\text {PrepP }}\end{array}$ \\
\hline \multirow{4}{*}{$\begin{array}{l}\text { Adj- } \\
\text { Phrase }\end{array}$} & Simple AdjP & {$[\text { evidente] }]^{\text {AdjP }}$} \\
\hline & $\begin{array}{l}\text { AdjP with pre/post- } \\
\text { modification }\end{array}$ & [extremadamente útiles] ${ }^{\text {Adjp }}$ \\
\hline & $\begin{array}{l}\text { AdjP with embedded } \\
\text { clause(s) }\end{array}$ & 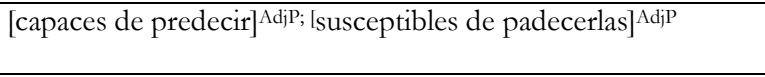 \\
\hline & $\begin{array}{l}\text { AdjP with pre/post- } \\
\text { modification and } \\
\text { embedded clause }(\mathrm{s})\end{array}$ & $\begin{array}{l}\text { [responsable del diferente papel que el enzima realiza en tejido } \\
\text { normal o en células tumorales] AdjP }\end{array}$ \\
\hline \multirow{2}{*}{$\begin{array}{l}\text { Adv- } \\
\text { Phrase }\end{array}$} & Simple AdvP & 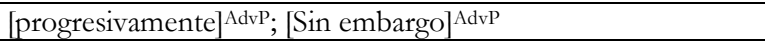 \\
\hline & $\begin{array}{l}\text { AdvP with pre- } \\
\text { modification }\end{array}$ & {$[\text { más fácilmente] }]^{\text {AdvP }}$} \\
\hline $\begin{array}{l}\text { Verb- } \\
\text { Phrase }\end{array}$ & $\begin{array}{l}\text { VP of finite independent } \\
\text { clause }\end{array}$ & Nuestro objetivo principal [es] $]^{\mathrm{VP}}$ intentar conseguir recaída $0 .$. \\
\hline
\end{tabular}

\subsection{Analytical procedures}

ATLAS.ti 8.3 was used to code all the textual material into phrase types and subtypes. DRAE, the Dictionary of the Academy of the Spanish Language and reference 
grammars of Spanish and English (Alarcos Llorac, 1999; Biber et al., 1999; Leech et al., 2009) assisted the coding process. Firstly, all the phrase constituents of every independent clause (or T-unit) were coded into the selected phrase types/subtypes. These different phrase structures were rank-ordered based on code frequency. In a subsequent coding stage the highly-frequent phrases were described functionally, that is, in terms of grammatical complexity, degree of explicitness and elaboration. This description aimed at characterising aspects of densification (i.e. high frequency of noncolloquial features) and compression/expansion (i.e. structural elaboration of the discourse) following Biber et al. (1999) and Leech et al. (2009).

To explore syntactic complexity in relation to phrase structures, the verb phrases of dependent clauses were coded and categorized into the following subtypes: VPs formed by non-finite (to+inf., -ing, -ed) clauses and VPs of finite dependent clauses (relative, complement, adverbial and comparative). This categorization was expected to provide information on the structural constituency of the phrasal post-modifiers of noun phrases and the syntactic complexity of the verbal predicates. Other constructs that measure syntactic complexity and elaboration, namely, average mean of words per sentence (sentence length) (Table 1) were also considered for interpreting the functional associations of the grammatical features identified in the coded material.

ATLAS.ti was preferred to other existing quantitative software tools for corpus linguistics research because, in addition to the above-mentioned options for data evaluation and analysis, it enables simultaneous coding of the linguistic and multimodal features of the videos that accompany the crowdfunding proposals. Comparing the communicative functions of the grammatical resources in the proposals along with those of their audiovisual narratives is also a prospective area of research to track cross-linguistic genre typification.

\section{Results}

Out of a total of 2,925 phrases coded in the present study, noun phrases and verb phrases were particularly frequent (Figure 1). NPs represented circa $45 \%$ of all phrases and amounted to 1,456 phrases (59.98 per 1,000 words). As also shown in Figure 1, VPs were the second most frequent type (approximately $30 \%$ of all phrases in the corpus, 938 occurrences and an average of 38.64 per 1,000 words). Reliance on the grammar categories of nouns is indicative of the high lexical density in these proposals. 


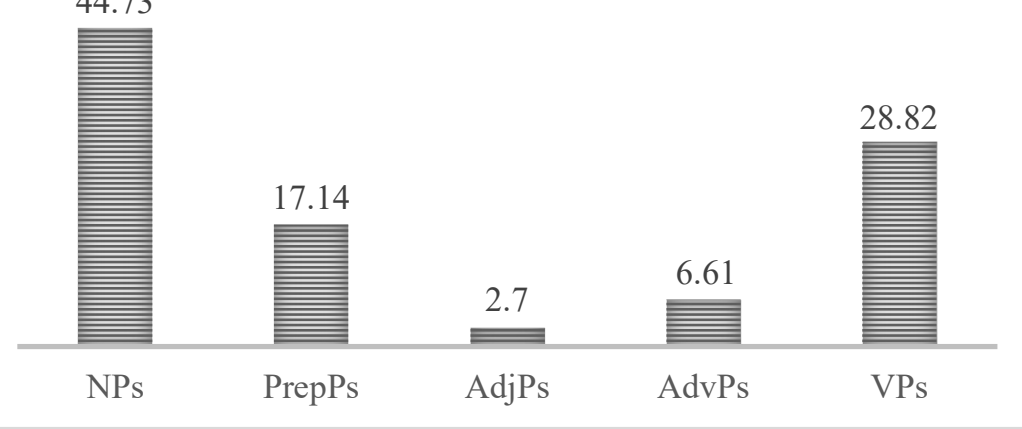

Figure 1. Comparative frequency of phrase types.

Table 3 shows the distribution of phrasal subtypes that account for grammatical complexity, or what Biber and Gray (2016) refer to as a 'structurally complex discourse style'. Noticeably, $70 \%$ of all NPs were complex structures with pre/postmodification and/or clausal embedding. While some frequencies per 1,000 words are extremely low, the cumulative frequency of NPs with pre/post-modification and NPs with pre/post-modification and clausal embedding (39.92) and the frequency of VPs (40.30) are very high.

Table 3. Distribution of phrasal subtypes.

\begin{tabular}{|l|l|l|l|}
\hline \multicolumn{1}{|c|}{ Phrasal subtypes } & Raw counts & $\begin{array}{c}\text { Frequency per } \\
\mathbf{1 , 0 0 0} \text { words }\end{array}$ & $\begin{array}{c}\text { Comp. } \\
\text { frequency } \\
\text { across subtypes }\end{array}$ \\
\hline Simple NP & 422 & 18.13 & 28.98 \\
\hline NP with pre/post-modification & 742 & 31.88 & 50.96 \\
\hline NP with embedded clause(s) & 105 & 4.51 & 7.21 \\
\hline $\begin{array}{l}\text { NPs with pre/post-modification and embedded } \\
\text { clause(s) }\end{array}$ & 187 & 8.04 & 12.84 \\
\hline Simple PrepP & 190 & 8.16 & 34.05 \\
\hline PrepP with pre/post-modification & 296 & 12.72 & 53.05 \\
\hline PrepP with embedded clause(s) & 28 & 1.20 & 5.02 \\
\hline $\begin{array}{l}\text { PrepP with pre/post-modification } \\
\text { embedding }\end{array}$ & 44 & 1.89 & 7.89 \\
\hline Simple AdjP and & 62 & 2.66 & 70.45 \\
\hline AdjP with pre/post-modification & 12 & 0.52 & 13.64 \\
\hline AdjP with embedded clause(s) & 6 & 0.26 & 6.82 \\
\hline $\begin{array}{l}\text { AdjP with pre/post-modification } \\
\text { embedded clause(s) }\end{array}$ & 8 & 0.34 & 12.12 \\
\hline Simple AdvP & 211 & 9.07 & 98.34 \\
\hline AdvP with pre/post-modification & 4 & 0.17 & 1.66 \\
\hline VP of independent clause (main clause) & 938 & 40.30 & N/A \\
\hline
\end{tabular}

As seen in Table 3, half of all NPs are complex structures consisting of a preand/or post-modified noun head. Often, evaluative adjectival pre-modifiers in complex NPs make explicit the significance of the project proposal and claim centrality of the research topic (examples 1-2). Additionally, these NPs contain several 
PrepP post-modifiers (e.g. [la sensibilidad [de la técnica [de la citometría de flujo $\left.\left.]^{\text {PrepP }}\right]^{\text {PrepP }}\right]^{\mathrm{NP}}$; [la implementación [de programas [de cribado] $\left.\left.{ }^{\text {PrepP }}\right]^{\text {PrepP }}\right]^{\mathrm{NP}}$. As seen in example 3, scientific jargon is used to provide detailed information, which in turn confers credibility to the statement.

(1) La leucemia aguda linfoblástica es [la enfermedad maligna más frecuente en la infancia, con una incidencia anual en torno a 4/1000000 niños] ${ }^{\mathrm{NP}}$

(2) [una importante aportación [en el concepto [de herencia epigenética] $\left.\left.]^{\text {Prepp }}\right]^{\text {PrepP }}\right]^{\mathrm{NP}}$

(3) [la comprensión [de los mecanismos catalíticos y moleculares [de las glicosiltransferasas y transglicosasas $\left.\left.]^{\text {PrepP }}\right]^{\text {PrepP }}\right]^{\mathrm{NP}}$

Instantiating processes of transmedial gradation (Engberg \& Maier, 2015), meanings conveyed in complex NPs with adjectival and/or PrepP post-modification are expanded by means of embedded finite and/or non-finite clauses that convey propositional contents in a concise manner and make the discourse highly informational. In this case, as in the traditional grant proposal, the project launchers clarify the status quo of the research under scrutiny (as in example 4), specify the target population and context of the research (example 5) or make explicit the need to further the research (example 6). By this means, readers do not need to infer meanings to understand what the research is about.

(4) [la herramienta más eficaz Relative clause -> [que tenemos en la actualidad To-inf. clause -> [para diagnosticar de forma precoz el CCR]] $]^{\mathrm{NP}}$

(5) Es [una aplicación clínica innovadora (sencilla, rápida, no invasiva, sin riesgos) de una técnica _Relative clause -> [que tradicionalmente se ha utilizado como técnica de referencia en investigación de macromoléculas]] ${ }^{\mathrm{NP}}$

(6) [aquellos pacientes inmunodeprimidos, [por enfermedad o por situación vulnerable comparative clause -> [como puede ser un ingreso hospitalario] ${ }^{\text {PrepP }}$, Relative clause -> [que hayan contraído una infección fúngica] $]^{\mathrm{NP}}$

NPs with embedded relative clauses define and clarify illnesses. Extended definitions of technicisms rely on complex NP structures with clausal embedding that make scientific contents understandable to an audience that may not have previous background knowledge to interpret them. As exemplified below, the main function of dependent clauses embedded in complex NPs is to recontextualise scientific discourse and adapt it to a non-expert audience. Example (7) shows how a specialist term such as antitombrina is paraphrased in plain terms by means of a non-restrictive (nondefining) relative clause. In example (8) the generic term medicamento is reformulated with specification/expansion by means of an appositional noun phrase. 
(7) [la antitrombina, Relative clause $->$ [que es un anticoagulante natural presente en nuestra sangre]] ${ }^{\mathrm{NP}}$, tiene capacidad anti-metastásica ya que inhibe la acción de ciertas proteínas.

(8) [un medicamento, apposition -> [un antagonista del ácido fólico], Relative clause $->$ [que consiguiera una remisión temporal en estos niños, Relative clause $->$ [que morían en 1-2 meses sin tratamiento]] $]^{\mathrm{NP}}$

It is also worth noting that both the online proposals and their corresponding expanded texts exhibit similar grammar features to provide very detailed explanations of scientific terms. Examples 9 and 10, illustrating structural elaboration at the level of syntax, reflect transmedial gradation processes. Scientists define specialised scientific terms by adjusting the informational load of the texts to an audience with different levels of expertise. By this means, readers are informed in detail about the scope and impact of the illness that is being investigated.

(9) La endometriosis es [un trastorno ginecológico crónico de causa desconocida [caracterizada por la presencia de tejido endometrial, funcionalmente activo, fuera de la cavidad uterina, [que provoca dolor, infertilidad] y [se asocia con cáncer ovárico]] ${ }^{\mathrm{NP}}$ (main text online)

(10) La endometriosis se considera [una patología inflamatoria, en la que los macrófagos (células centinela encargadas de detectar la presencia de microorganismos, fagocitarlos, activar a los linfocitos $\mathrm{T}$ y producir mediadores de la inflamación, entre otras muchas funciones) juegan un papel relevante] $]^{\mathrm{NP}}$ (expanded text in $\mathrm{pdf}$ )

It is also worth noting that complex NP structures occur in simple syntactic patterns (e.g. Subject-Verb-Subject Predicative) and convey semantic meanings in a very concrete way:

(11) Es [una aplicación clínica innovadora (sencilla, rápida, no invasiva, sin riesgos) de una técnica_relative clause -> [que tradicionalmente se ha utilizado como técnica de referencia en investigación de macromoléculas]] $]^{\mathrm{NP}}$

These complex NPs do not condense information into single packagings as noun compounds do in English academic prose (Biber et al., 1999) because in the Spanish grammar system nouns cannot function as noun pre-modifiers. Rather, noun phrases are expanded in many ways constructing relatively long sentences that expand contents further, making the texts informationally dense and meaningful. This is a typical feature of written registers in Spanish. In contrast, English academic prose that is characterised by structural compression (Biber et al., 2008; Parodi, 2010).

Regarding verb-phrases (VPs) of independent clauses, that is, those that "stand alone without being subordinate to another clause" (Biber et al., 1999: 224), the coding process revealed that many of them contained the Spanish copula verb ser (be) 
acting as phrase head. These grammar patterns introduce non-technical definitions of specialised terminology, explanations of illnesses and/or state the existence of conditions that need addressing, such as the low survival rates of an illness, or the incidence of the illness in a given population. The description of specialised contents facilitates understanding of the scope of the illness that is being investigated. Interestingly, all the introductory sentences of the online proposals contained VPs with primary verb heads that link the research to society, claiming relevance of the proposal, as illustrated in example 12.

(12) El cáncer de colon [es] ${ }^{\mathrm{VP}}$ [uno de los problemas de salud pública más graves del siglo XXI $]^{\mathrm{NP}}$

VPs with copula be are generally followed by an embedded to-infinitive complement clause. Often, these clauses contain further clausal embedding, thus reflecting structural elaboration at the level of grammar:

(13) El objetivo de nuestro grupo [es] ${ }^{\mathrm{VP}}$ totinf complement clause $->$ [analizar la seguridad y la eficacia de la transferencia de bacterias intestinales encapsuladas procedentes de donantes sanos a pequeñas dosis y de manera repetida a pacientes con VIH]

(14) Nuestro objetivo principal [es] ${ }^{\mathrm{VP}} T_{o}+$ inf complement clause $->$ [estudiar los fenómenos celulares y moleculares Relative clause $->$ [que se encuentran asociados al efecto beneficioso de aplicación de membrana amniótica en estas heridas]

VPs formed by lexical verbs in the simple present, past or present perfect describe medical treatments and procedures related to the illness. They generally occurred in the passive voice, without specifying the agent of the action (e.g. se caracterizan (are characterised), son tratados (are treated), se encontraron (were found), se utilizaron (were used), se describieron (were described), se han observado (have been observed)). Used in the present perfect tense and encapsulating first person plural pronoun references, these grammar patterns explicitly inform about the activities carried out by the team of researchers (e.g. hemos conseguido (we have obtained), hemos desarrollado (we have developed), hemos descubierto (we have found)).

VPs containing reporting verbs (e.g. mostrar (show), demostrar (demonstrate), indicar (indicate)) provide factual evidence and state previous scientific achievements of the research group in a very explicit way. These verbal structures convey credibility, as reporting verbs do in other genres such as personal academic homepages (Hyland, 2010). Non-finite VPs (that-complement clauses) controlled by these VPs are recurring devices for structural elaboration and are used to describe, clarify and underline the value of the expected outcomes of the project proposals.

(15) La distribución por sexos [demuestra] ${ }^{\mathrm{VP}}$, tanto en niños como en adultos, Thatcomplement clause -> [que los varones son más propensos a cumplir los criterios para 
el diagnóstico de TDAH, especialmente para el subtipo combinado, Comparative clause $->$ [mientras que las mujeres son más proclives a cumplir los criterios para el subtipo inatento]

(16) La experiencia descrita en el laboratorio Oncología Molecular y TGFß [muestra] ${ }^{\mathrm{VP}}$ las capacidades disponibles del grupo y el instituto de investigación anfitrión, ed participle clause -> [avaladas por una producción científica exitosa y un historial de colaboración internacional]]

A salient finding was the recurrence of VPs containing modals and semi-modals such as poder (can), deber de (must), necesitar (need), tener que (have to), verbs with modal meanings that act as modal auxiliaries in Spanish, such as pretender (seek), querer (want to), proponerse (aim to) as well as periphrastic modals such as ir a (be about to) (De Kock \& Gómez Molina, 2002; Parodi, 2015). These various VPs specify the meaning of the accompanying infinitive verb and denote epistemic possibility, prediction and volition. Additionally, these verb structures, that embed dependent finite and nonfinite clauses and/or phrasal and clausal coordination, create an elaborate discourse style, which is highly explicit in meaning. At times, accompanied by evaluative markers emphasising the need for funding:

(17) Ahora y con vuestra ayuda [podemos determinar] ${ }^{\mathrm{VP}}$ that-complement clause $->$ [qué factores moleculares actúan en el proceso de cicatrización de las úlceras de pie diabético] to + inf. clause $\rightarrow$ [para poder resolver la úlcera en el menor tiempo posible]

(18) $[\text { Queremos desarrollar }]^{\mathrm{VP}}$ una vacuna $\underset{\downarrow}{\mathrm{V}}$ un tratamiento to + inf. clause $->$ [para luchar contra esta enfermedad -ing gerund clause $>>$ [aplicando la nanobiotecnología, Relative clause $->$ [que es una magnífica herramienta to + inf. clause $->$ [para introducir los principios activos hasta las células diana en los procesos patológicos humanos y animales]]]

(19) Con este proyecto [se pretende mejorar] ${ }^{\mathrm{VP}}$ la calidad de vida de los pacientes $\underline{\mathrm{V}}$ su integridad física, [reducir] ${ }^{\mathrm{VP}}$ los costes sanitarios Relative clause $->$ [que generan

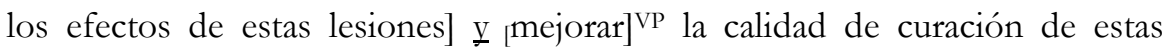
úlceras to + inf. clause $->$ [para que no vuelvan a producirse]]

The most frequent modal verb in VPs, the modal poder (can), signalled tense variation in Spanish. Unlike English, this is possible in Spanish. In the data analysed this modal was used in the future tense to express certainty (podremos/will be able to) and in the conditional tense (podriamos/would be able to) to convey prediction and/or speculation (examples 20-21). VPs with poder were followed by complex NPs and PrepPs containing finite clauses and/or embedded clauses, often in chains of coordinated to-infinitive clauses (example 22). The result is a structurally elaborate discourse, highly informational and with a high degree of explicitness. The corpus data further shows that first person plural verb forms (-mos) are used rhetorically to convey 
professionalism and explicitly emphasise the expected accountability of the results if the funding is obtained.

(20) Si logramos el objetivo máximo [podremos además mejorar] ${ }^{\mathrm{VP}}$ el tratamiento de estos pacientes con una tecnología más avanzada Relative clause -> [que nos permita clasificaciones de heridas en función de parámetros moleculares determinados]

(21) Con este array de expresión [podríamos incluso identificar] ${ }^{\mathrm{VP}}$ otras dianas moleculares Relative clause -> [que contribuyan a las características clínicobiológicas de estos tumores]

(22) Si se superara el objetivo óptimo [podríamos contratar] ${ }^{\mathrm{VP}}$ personal predoctoral to+inf. clause -> [para ampliar y to+inf. clause $->$ [optimizar los objetivos del proyecto y la obtención de resultados], to + inf. clause $->$ [redactar nuevas publicaciones] y to + inf. clause $->$ [sufragar el coste de publicación en revistas de acceso abierto]

Also, overt statements of the necessity of funding were formulated with the modal of obligation tener que (have to), at times conveying epistemic necessity and, at other times, deontic meaning (strong obligation). These VPs encapsulated first person plural we-pronoun references emphasising the research team's professionalism. Clausal embedding, mainly in non-finite VP structure forms, was used to convey credibility and professionalism and, at the same time, highlight the importance of raising funds.

(23) [Tenemos que realizar la validación del método en la mayor población posible to+inf. clause -> [para evaluar sensibilidad, especificidad y robustez del test] $]^{\mathrm{VP}}$

Lastly, VPs controlled embedded finite/non-finite dependent clauses that conveyed means (through -ing gerund clauses), stated reasons (through reasons/result clauses), expressed purpose (through to-infinitive clauses) and provided detailed indications and concrete aspects of each project proposal (through relative clauses). As shown in the examples below, these types of embedding create an elaborate discourse style, very common in formal Spanish written texts (Biber et al., 2008).

(24) Este proyecto es único y singular Reason/result clause -> [porque hasta ahora no se ha desarrollado ningún algoritmo, ningún modelo matemático Relative clause $->$ [que permita identificar nuevos marcadores biológicos útiles To-inf. clause -> [para redefinir la estratificación en grupos de riesgo Means/end clause -> [usando la enorme cantidad de datos ya existentes]]]

\section{Discussion}

The aim of the present study was to explore the linguistic features that characterise crowdfunding project proposals, a genre that is increasingly popular among researchers to disseminate science beyond expert audiences and, at the same time, to 
prompt donation for supporting their scientific work. The specific aim of the study was to provide a linguistic characterisation of this digital genre and identify the functional associations of its recurring grammar features.

In response to RQ1: 'What grammatical features characterise the genre of crowdfunding project proposals and what are the functions of these features in communicating meaning?', the findings of the present study indicate that these proposals rely heavily on the use of phrasal patterns, being noun phrases the most frequent phrase type (almost half of all phrase types coded in the corpus). The fact that both the online and the expanded texts of the proposals were built upon "more nominal than verbal" patterns (Biber \& Gray, 2010) suggests that nouns are core linguistic features in this genre. The presence of nouns, an "especially common grammar feature in academic prose" (Biber \& Gray, 2016: 318), indicates that one function of nominal patterns is to provide information about the science being crowdfunded. As a further exploration, the constructs of tokens, types and type-token ratio (TTR) of each of the proposals (Table 1), and the average means of these constructs in the overall corpus (1213.65 tokens, 448.9 types or distinct words and an average TTR of 40.63) indicate a relatively low lexical variety. This points to the fact that the texts do not show high dependence on shared contextual knowledge with their intended readership, which is not an unexpected finding considering that the proposals mainly target a non-specialist, diversified audience.

Tracing grammar features also proved useful to understand processes of transmedial gradation (Engberg \& Maier, 2015) in this digital genre. The proposals exhibited a high frequency of NPs containing pre-/post-modification and NPs with embedded clauses, mainly, relative clauses with restrictive and non-restrictive functions. As seen in the corpus, it is through these complex nominal patterns that specialised knowledge is made accessible to a lay audience. For instance, this has been seen in extended definitions of scientific terms that presented information concisely and efficiently. While the former type of NP structures made the intended referent of the head noun explicit, the function of the latter NP type was to clarify and further elaborate scientific contents. Even if, unlike English, nouns in Spanish cannot be noun pre-modifiers, there seems to be evidence in the data analysed that these complex grammar structures illustrate processes of meaning expansion. Supporting previous descriptions of genres in new media environments (Herring, 2013; Gross \& Buehl, 2016; Kelly \& Miller, 2017), it can be claimed that the function of complex NPs is to recontextualise expert scientific contents to reach what Burns et al. (2003) define as audiences with different backgrounds, interests and expectations. This claim is consistent with previous functional characterisations of linguistic features in other digital genres of science and science popularisation genres in diverse languages English, Spanish and Portuguese, among others. In those instances, linguistic features serve to explain the "specialised terms in the field of study" (Motta Roth \& Scotti 
Scherer, 2016: 189) and clarify scientific contents in a concise manner (Caliendo, 2012; Gotti, 2014; Scotto di Carlo, 2014; Motta Roth \& Scotti Scherer, 2016; Luzón, 2017).

Aligning with rhetorical studies of crowdfunding proposals (Mehlenbacher, 2017; Paulus \& Roberts, 2018), the present linguistic analysis suggests that the functionality of grammar features is a response to the rhetorical situation underpinning the genre as social action. As seen in the Precipita projects, both the online texts and their corresponding expanded texts fulfil several functional goals. They do not only inform about scientific research, but also claim centrality, create credibility and appeal to an emotional response on the part of the reader. A similar argument is found in Paulus and Roberts' (2018: 64) study online medical campaigns. As these authors contend, on the web linguistic resources construct strong identities — "real-life superheroes" - to construct an emotionally appealing discourse that prompts funding to cover their medical costs.

The functionality of grammar features in the crowdfunding proposals, namely to claim factual evidence and build convincing arguments, is also worth discussing in relation to the high frequency of verbal phrases. In the corpus there were instances of VPs with action verbs as VP heads that conveyed information on scientific procedures. There were also VPs with reporting verbs that provided evidential facts that served as a basis to build arguments and foreground the researchers' credentials (both their previous and current work on the research topic). Additionally, VPs with copula 'be' in SVSP syntactic constructions, being the copular verbs of these copular predicates frequently followed by 'to'-infinitive complement clauses, expressed the relevance of the research and were associated with functions such as conveying credibility and demonstrating that the 'science' researchers do has potential for addressing social concerns, specifically, for providing solutions to health and wellbeing problems in society. Also recurring were verbal phrases containing core modals, semimodals or periphrastic modals, containing first person pronoun references, denoted epistemic possibility and volition, necessity, obligation and certainty meanings. The range of modal meanings conveyed in the texts recalls the use of modality in the conversational register, differing notably from the deployment of modality in formal academic written texts, where degrees of tentativeness are expressed through the modals 'may' and 'might' (Biber et al., 1999). Leech et al. (2009) explain that the semimodal 'have to', an epistemic variant of the obligation modal 'must', expresses strong obligation but does so "in a less authoritarian way", thus making a "less facethreatening impression" (Leech, 2009: 115). However, the corpus data did show that even the Spanish semi-modal tener que used in some of the verb phrases did not fully function as a less face-threatening variant of the modal deber (see De Kock \& Gómez Molina, 2002), but rather as a marker of assertiveness.

Regarding RQ2: 'What is the discourse style of crowdfunding projects in terms of grammatical complexity, elaboration and degree of explicitness of meanings?', this 
exploratory study strongly suggests that grammar is a key language variable that shapes the discourse style of this genre and, above all, that language forms "functionally match the requirements" of a particular situation (Biber \& Conrad, 2019). Supporting the claim that emerging genres in the Internet draw on features of existing genres (Herring, 2013; Giltrow, 2017), the discourse style of the proposals proved to be to some extent similar to that of an already existing genre, the research project proposal: a style characterised by structurally complex grammar patterns that convey information very explicitly and, therefore, a style strongly associated with densification and economy. This is precisely the style of informational registers in English and Spanish (Biber et al., 1999; Parodi, 2010, 2015; Biber \& Gray, 2016; Biber \& Conrad, 2019). Both genres actually seek similar rhetorical goals — paraphrasing Mehlenbacher (2017), to establish an exigence and a response, to occupy the response, to claim benefits and to claim the researchers' competence and the importance of their research in order to raise funding.

This study also provides evidence of processes of densification and economy. The grammar features identified in the proposal conveyed a high amount of information in a relatively limited space (an average of 800 words), making very explicit the research project goals and its expected outcomes. The presence of complex NPs embedding adjectival pre/post-modification, and/or prepositional phrases acting as noun postmodifiers and/or finite/non-finite dependent clauses suggests that grammar choice is crucial to scaffold compelling scientifically-based arguments and persuade nonspecialist audiences to fund scientific research. It is worth recalling here that such syntactic complexity was nonetheless less lexically varied and dense than the syntax associated with academic prose and other written registers such as fiction and journalism (Biber et al., 1999; Parodi, 2015; Biber \& Gray, 2016).

From a genre perspective, it is likely that the form of the crowdfunding projects has not yet fully stabilised, and that it is still subject to evolution and change, as is also the case of other digital genres (Giltrow, 2017: Giltrow \& Stein, 2009). The constructs for measuring syntactic complexity remain somewhat inconclusive, as they indicated a relatively high variation across proposals and within each individual proposal. The average means (in words) per sentence of the different project proposals ranged from 20.79 to 31.21 words per sentence, a rather ample range of variation, which suggests that structural elaboration is not distributed evenly across the sentences of each proposal and across the proposals. Similarly, the standard deviations of the different proposals (ranging from 11.60 to 22.28) and that of the overall corpus (15.75) showed high coefficients of variation (in all cases the CVs were $>1$ ), indicative of a fair amount of variance regarding syntactic complexity. Evolution and change of linguistic features in this genre are therefore issues that need to be further investigated in future research. 
Regarding cross-linguistic comparisons, in the corpus analysed there is preliminary evidence that the discourse style of the proposals is comparable to the style characterising formal registers in English and Spanish. The analytical approach used in the present study identified complex NPs with multiple embeddings (above all, NPs with prepositional phrases acting as nominal post-modifiers), as well as VPs controlling dependent finite subordinate clauses (especially, relative clauses), nonfinite relative clauses and that-noun complement clauses. These are characteristic features of formal academic writing in English (Biber \& Gray, 2016). Other syntactic structures found in the proposals such as clausal subordinate clauses, conditional subordinate clauses, que-verb complement clauses and que-relative clauses, also revealed linguistic similarities with academic written Spanish (Biber et al., 2008). Because the criterion of 'discourse organisation mode' is operationalised in linguistic features associated with degrees of grammatical complexity (Parodi, 2015), it seems reasonable to claim that the discourse organisation mode of the proposals - both descriptive and argumentative- fits within the 'informational focus' dimension proposed for describing academic genres in Spanish (Parodi, 2010, 2015).

Previous rhetorical and linguistic studies contend that colloquial features associated with conversation can be traced across genres and new forms of communication in Web 2.0 (Luzón, 2013; Mancera \& Pano, 2013; Barbieri, 2018; Mancera, 2018; Moya \& Carrió-Pastor, 2018a, 2018b). One linguistic difference between Spanish and English that needs to be addressed in the analysis of crowdfunding proposals concerns the issue of structural elaboration vs. structural compression. In English academic writing "phrasal (non-clausal) modifiers embedded in noun phrases are the major type of structural complexity" (Biber \& Gray, 2010: 3), rendering a compressed style that packages information into nominal compounds that condense information in chunks and is thus "efficient for expert readers, who can quickly extract large amounts of information from relatively short, condensed texts" (Biber \& Gray, 2016: 326). Yet, the Spanish proposals differed in that phrasal post-modifiers in noun phrase structures reflected structural elaboration and not compression. The reason is that in Spanish nouns cannot function as nominal pre-modifiers and prepositional phrases can only perform nominal post-modifying functions.

Although, as noted, the discourse style of the proposals relies on features that make texts cognitively dense (e.g. the presence of nouns, prepositional phrases as nominal post-modifiers and dependent clauses, particularly relative clauses, non-finite relative clauses, that-noun complement clauses), this study also brings in the issue of colloquialisation in written texts in the Internet. The proposals contained linguistic features associated with academic written registers, such as verb phrases, action verbs, lexical verbs, modals and semi-modals (Biber \& Gray, 2016), as well as colloquial features (deictics, person pronouns, intensifiers) encapsulated in nominal structures. These colloquial features even appeared in definitions of scientific terms were and 
descriptions scientific facts and procedures to construct "a mutual frame of reference" (Hyland, 2010: 213), as also happens in other digital genres such as science blogs and popularisations, online comments and reviews in digital media (Mancera \& Pano, 2013; Barbieri, 2018; Moya \& Carrió-Pastor, 2018a, 2018b). The merge of both formal and informal discourse styles in the crowdfunding proposals, making readers more predisposed to accept scientific facts and, hence, more easily persuaded to support research financially, aligns with Giltrow (2017) and Herring's (2013) conceptualisation of digital genres as generic hybrids.

Lastly, in response to RQ3: 'What situational and genre constraints account for the communicative functionality of the grammar of these projects?', the study findings suggest that grammar use is a rhetorical exigence of the genre. Grammar constraints therefore appear to account for the fact that this digital genre targets at audiences with diverse interests and backgrounds, as is also the case of other digital genres (Caliendo, 2012; Luzón, 2013; Scotto di Carlo, 2014) and forms of Internet-mediated science communication (Mancera \& Pano, 2013; Biber \& Conrad, 2019). In the crowdfunding proposals, the function of complex noun phrases was not to elaborate theories, provide conceptual or theoretical discussions or report empirical findings in a technical manner, all of them primary functions of the grammar of academic prose (Biber et al., 1999). Rather, through nominal and verbal phrase structures scientists inform about science in a concise manner, recontextualise scientific discourse and clarify expert knowledge. In terms of cognitive processing, the grammatical constituents of the proposals do not therefore pose difficulties for non-specialist readers, who are given clear and concise information on the scientific research that the research group is investigating, as well as convincing reasons to justify the need for funding. It is nonetheless important to bear in mind that, unlike other digital genres and new forms of communication in Web 2.0 (Gotti, 2014; Hyland, 2010, 2018; Motta Roth \& Scotti Scherer, 2016; Luzón, 2017), these proposals do incorporate scientific jargon while making informational adjustments to reach a lay audience drawing on specific grammatical patterns - e.g. structurally elaborated noun phrases containing prepositional phrase post-modifiers, non-restrictive appositive noun phrases, parentheticals and/or defining -ed participle clauses. These patterns are a response to the need to manage knowledge asymmetries and ensure that the information is conveyed efficiently, as the situational demands of the genre require so.

It can also be concluded that, along with the rhetorical organisation of the proposals (see Mehlenbacher, 2017; Paulus \& Roberts, 2018), the functionality of the grammatical characteristics of the proposals makes these texts highly informative, persuasive and appealing to broad audiences. In addition to facilitating understanding of science, processes of densification and economy seem to be a response to the primary communicative goals of this genre, namely, conveying credibility and trust to prompt donation. As Mehlenbacher (2017) concludes, these proposals 'create a 
persuasive appeal' through rhetorical moves/steps that establish an exigence and the need for a response and provide a solution, claiming professional competence and the importance of supporting science through donation.

The present study also sheds light on the situational (register) and contextual (genre) constraints that shape digital texts. In TED Talks, presenters use a conversational style to tell issues of science and the use of linguistic resources such as first and second person pronouns reduces distance "to breach the expert/non expert barrier" (Scotto di Carlo, 2014: 201). In research blogs, conversational features construct proximity (Luzón, 2013), and in online medical campaigns language resources help scientists to construct credible identities (Paulus \& Roberts, 2018). In analysing science popularisation genres, Motta Roth and Scotti Scherer (2016: 173) also underline the "interdiscursivity between discourses from scientific, pedagogic and media spheres". In the crowdfunding proposals analysed in this study, the situational and contextual constraints easily explain why these texts rely on both grammatical features that are typical of conversation and features characteristic of formal academic prose. They need to 'tell' as well as to 'sell' scientific research. In incorporating features of both scientific discourse, didactic discourse and persuasive discourse, the present analysis supports the view that "the media context is constituted as a space between the primary 'context of production' of scientific research and 'non-specialist contexts' of wider society” (Motta Roth \& Scotti Scherer, 2016: 174).

In tracing modality in phrase-level constituents, this study further suggests that linguistic features in digital genres of science play an important role in 'selling' scientific research. In fact, the analysis of the crowdfunding proposals showed that the functional association of verbs marked by modal verbs was to boost the illocutionary force of the utterances rather than to tone it down. A case in point was the use of the semi-modal querer (want to), that has "a directive, or quasi-imperative function" (Leech et al., 2009: 114). As stated above, this semi-modal conveyed personal meanings of volition or intention, even intrinsic obligation meanings. Modal markers and first person plural pronoun references encapsulated in nominal and verbal phrases did not function as linguistic resources to reduce distance as in blogs (Luzón, 2017), TED Talks (Scotto di Carlo, 2014) or online reviews (Mancera, 2018). Rather, they convey professionalism and build credibility and trust in scientific research.

Turning to the broader implications of Web 2.0 for science communication, and acknowledging the limitations of the corpus size, the present study lends credence that orality, formality, efficiency and expressivity (Herring, 2013) are valid constructs to understand the form and substance of emerging digital genres. Accordingly, linguistic innovations (Giltrow \& Stein, 2009; Giltrow, 2017) should be investigated in greater depth to gain a better understanding of the construction of digital genres that draw on existing genres and exploit the affordances of Web 2.0. As Parodi (2010: 17) sensibly remarks, linguistic features link the contextual and the cognitive aspects underlying 
textual construction and interpretation. Because science communication is multilingual, cross-linguistic comparisons of this digital genre seem germane to the future research agenda.

\section{REFERENCES}

Alarcos Llorach, E. (1999). Gramática de la lengua española. Madrid: Espasa Calpe.

Barbieri, F. (2018). I don't want to and don't get me wrong: Lexical bundles as a window to subjectivity and intersubjectivity in American blogs. In J. Kopaczyk \& J. Tyrkkö (Eds.), Applications of pattern-driven methods in corpus linguistics (pp. 251-276). Amsterdam: John Benjamins.

Biber, D. \& Conrad, S. (2019). Register, genre and style. Cambridge: Cambridge University Press.

Biber, D., Johansson, S., Leech, G., Conrad, S. \& Finegan, E. (1999). Longman grammar of spoken and written English. London: Longman.

Biber, D., Davies, M., Jones, J. K. \& Tracy-Ventura, N. (2008). Spoken and written register variation in Spanish: A multi-dimensional analysis. Corpora, 1(1), 1-37. https://doi.org/10.3366/cor.2006.1.1.1

Biber, D. \& Gray, B. (2010). Challenging stereotypes about academic writing: Complexity, elaboration and explicitness. Journal of English for Academic Purposes, 9(1), 2-20. https://doi.org/10.1016/j.jeap.2010.01.001

Biber, D. \& Gray, B. (2016). The competing demands of popularisation vs. economy: Written language in the age of mass literacy. In T. Nevalainen \& E. C. Traugott (Eds.), The Oxford handbook of the history of English (pp. 314-328). Oxford: Oxford University Press.

Burns, T. W., O’Connor, D. J. \& Stocklmayer, S. M. (2003). Science communication: A contemporary definition. Public Understanding of Science, 12(2), 183-202. https:/ / doi.org/10.1177/09636625030122004

Caliendo, G. (2012). The popularisation of science in web-based genres. In G. Caliendo \& G. Bongo (Eds.), The language of popularisation: Theoretical and descriptive models (pp. 101-132). Bern: Peter Lang.

De Kock, J. \& Gómez Molina, C. (2002). Gramática española. Enseñanza e investigación. Salamanca: Ediciones Universidad de Salamanca. 
Engberg, J. \& Maier, C. D. (2015). Exploring the hypermodal communication of academic knowledge beyond generic structures. In M. Bondi, S. Cacchiani \& D. Mazzi (Eds.), Discourse in and through the media: Recontextualizing and reconceptualizing expert discourse (pp. 46-65). Newcastle upon Tyne: Cambridge Scholars.

Giltrow, J. (2017). Bridge to genre: Spanning technological change. In C. R. Miller \& A. Kelly (Eds.), Emerging genres in new media environments (pp. 39-61). London: Palgrave Macmillan.

Giltrow, J. \& Stein, D. (2009). Genres in the Internet. Innovation, evolution and genre theory. In J. Giltrow \& D. Stein (Eds.), Genres in the Internet. Issues in the theory of genre (pp. 1-26). Amsterdam: John Benjamins.

Gotti, M. (2014). Reformulation and recontextualisation in popularisation discourse. Ibérica, Journal of the European Association of Languages for Specific Purposes, 27, 1534.

Gross, A. \& Buehl, J. (Eds.), (2016). Science and the Internet: Communicating knowledge in a digital age. Amityville, NY: Baywood Publishing Company.

Herring, S. (2013). Discourse in Web 2.0: Familiar, reconfigured, and emergent. In D. Tannen \& A. Trester (Eds.), Discourse 2.0 (pp. 1-25). Georgetown: Georgetown University Press.

Hyland, K. (2010). Constructing proximity: Relating to readers in popular and professional science. Journal of English for Academic Purposes, 9(2), 116-127. https://doi.org/10.1016/j.jeap.2010.02.003

Hyland, K. (2018). Narrative, identity and academic storytelling. ILCEA Revue de l'Institut des langues et cultures d'Europe, Amérique, Afrique, Asie et Australie, 31 [on line]. Retrieved from: http://journals.openedition.org/ilcea/4677

Kelly, A. R. \& Miller, C. R. (2016). Intersections: Scientific and parascientific communication on the Internet. In A. Gross \& J. Buehl (Eds.), Science and the Internet: Communicating knowledge in a digital age (pp. 221-245). Amityville, NY: Baywood.

Leech, G., Hundt, M., Mair, C. \& Smith, N. (2009). Change in contemporary English: A grammatical study. Cambridge: Cambridge University Press.

Luzón, M. J. (2013). Public communication of science in blogs: Recontextualizing scientific discourse for a diversified audience. Written Communication, 30(4), 428-457. https://doi.org/10.1177/0741088313493610 
Luzón, M. J. (2017). Connecting genres and languages in online scholarly communication: An analysis of research group blogs. Written Communication, 34(4), 1-31. https://doi.org/10.1177/0741088317726298

Mancera, A. (2018). La atenuación lingüística en las reseñas digitales de hoteles y restaurantes en español. Círculo de Lingüistica Aplicada a la Comunicación CLAC, 73, 53-76. http://dx.doi.org/10.5209/CLAC.59059

Mancera, A. \& Pano, A. (2013). El español coloquial en las redes sociales. Madrid: Arco Libros.

Mehlenbacher, A. R. (2017). Crowdfunding science: Exigencies and strategies in an emerging genre of science communication. Technical Communication Quarterly, 26, 127-144. https://doi.org/10.1080/10572252.2017.1287361

Miller, C. R. \& Kelly, A. (Eds.) (2017). Emerging genres in new media environments. London: Palgrave Macmillan.

Motta Roth, D. \& Scotti Scherer, A. (2016). Science popularisation: Interdiscursivity among science, pedagogy, and journalism. Bakbtiniana, 11(2), 171-194. http://dx.doi.org/10.1590/2176-457323671

Moya, P. \& Carrió-Pastor, M. (2018a). La atenuación en los comentarios sobre las noticias digitales en periódicos de España y Chile. Onomázein, 40, 56-76.

Moya, P. \& Carrió-Pastor, M. (2018b). Estrategias de intensificación en los comentarios digitales sobre noticias en español. Spanish in Context, 15(3), 369391.

Parodi, G. (Ed.) (2010). Academic and professional discourse genres in Spanish. Amsterdam: John Benjamins.

Parodi, G. (2015). Variation across university genres in seven disciplines. A corpusbased study on academic written Spanish. International Journal of Corpus Linguistics, 20(4), 469-499. https://doi 10.1075/ijcl.20.4.03par

Paulus, T. M. \& Roberts, K. R. (2018). Crowdfunding a "real-life superhero": The construction of worthy bodies in medical campaign narratives. Discourse, Context \& Media, 21, 64-72. https://doi.org/10.1016/j.dcm.2017.09.008

Scotto di Carlo, G. (2014). The role of proximity in online popularisations: The case of TED talks. Discourse Studies, 16(5), 591-606. https://doi.org/10.1177/1461445614538565 


\section{NOTE}

${ }^{1}$ Precipita https://www.precipita.es/

\section{ACKNOWLEDGEMENTS}

This article is a contribution to project FFI2015-68638-R MINECO/FEDER, EU, funded by the Spanish Ministry of Economy and Competitiveness and the European Social Fund. 